\title{
Proximate Analysis, Photochemical Screening And Antiplasmodial Potentials Of Mucuna Pruriens Leaves
}

\author{
Okere O. Shekins ${ }^{1}$, Iliemene Uju Dorathy*¹, Mubarak Liman ${ }^{2}$, Olowoniyi \\ Olufunsho Dayo ${ }^{3,}$ Nmadu P. $\mathrm{M}^{4}$ \\ 1. Department of Biochemistry, Bingham University, karu, Nigeria. \\ 2. Department of Biochemistry Ahmadu Bello University, Zaria, Nigeria. \\ 3. Department of Science Laboratory Technology, Fedral Polytechnic, Nasarawa, Nigeria. \\ 4. Department of Biological Sciences, Bingham University, karu, Nigeria.
}

\begin{abstract}
The proximate analysis of the Mucuna pruriens leaves according to AOAC (1990) shows appreciable amount of nutrients with highest carbohydrate content (45.65\%) and crude fat having the lowest value $(2.97 \%)$. There were presence of phytochemical compounds in the leaves ethanol extract following the method of Trease and Evans (1983). The antiplasmodial potential of the ethanol leaf extract of Mucuna pruriens was evaluated against Plasmodium falciparum in mice, after intraperitoneally malaria-induced mice, using parasitized $\mathrm{O}^{+}$ human blood. Parasitamia was confirmed 72 hours after induction, by viewing a thick and thin field stained (A and B) smear of the parasitized blood under low power microscope (x10) field. The level of parasitamia per field was recorded during the period of experimentation. The amount of food intake was also determined. The standard control group was treated with artesunate. High deposits of parasitaemia were observed on the first day of treatment, but this reduced significantly on the third day. Experimental animals treated with lowest dose of extract $(40 \mathrm{mg} \mathrm{kg}$ ) reduced parasitaemia level from 23 on the day 1 to 12 on the day 3, while the group treated with highest dose of extract $(120 \mathrm{mg} / \mathrm{kg})$ reduced parasitaemia level from 12 parasites per field to 8 parasites per field by the third day. These results imply that Mucuna pruriens has antiplamodial potential which might be attributed to the phytochemical and secondary metabolites contents of the plant and, its also does dependent. The appetite level of the experimental animals also increased, as the parasitaemia level decreased.
\end{abstract}

Key words: proximate analysis, phytochemical screening, Antiplasmodial, Mucuna pruriens

\section{Introduction:}

Medicinal plants are defined as any plants which contain substances that can be used for therapeutic purposes in one or more of its organ or substances which are precursors for the synthesis of useful drugs (Sofowora, 1982). Furthermore, Elujoba (1997) noted that a plant become a medicinal plant only when its biological activity has been ethnobotanically reported or scientifically established. Plants are great source of medicines, especially in traditional medicine, which are useful in the treatment of various diseases (Bako et al., 2005).

Mucuna pruriens is an annual climbing legume that grows 3-18 $\mathrm{m}$ in height, indigenous to tropical regions, especially Africa, India, and the West Indies. M. pruriens is locally known as werepe (Yoruba), agbala (Igbo) and Karara (Hausa). It is wide spread over most of the subcontinent and is found in bushes, hedges, and dry-deciduous, low forests throughout the plains of India (Sastry and Methrotas, 1991). Mucuna pruriens belongs to the family Fabaceae. Some other common names include: Common Cowitch, Konch, mucuna, nescafé, pó de mico, fava- coceira, cabeca-de-frade, cowage, cowhage, Bengal bean, Mauritius bean, itchy bean, krame, picapica, chiporro, and buffalo bean (Sastry and Methrotas, 1991).

In Nigeria, people in the rural area mostly are known for using natural herbs and herbal formulae for addressing various kinds of blood deficiencies. In south-eastern Nigeria, the leaves of Mucuna pruriens are considered excellent natural herbal blood boosters, used especially for debilitating conditions, acute blood loss and blood deficiency diseases (Obadoni and Ochuko, 2001). The roots are bitter, sweet, thermogenic, emollient, diuretic, purgative, aphrodisiac and stimulant. The leaves are also aphrodisiac. The seeds are astringent, laxative, anti-helminthes, alexipharmic and tonic (Taylor, 2005). A clinical study confirmed the efficacy of the seeds in the management of Parkinson's disease by virtue of their L-DOPA content (Manyam et al., 2004).

M. pruriens has been shown to increase testosterone levels (Amin et al., 1996), leading to deposition of protein in the muscles and increased muscle mass and strength (Bhasin et al., 1996). The itch-producing property and resulting blisters and dermatitis of M. pruriens is attributed to the trichomes (hair) present on the pods. It has been established that this unique property is accounted by the presence of 5-hydroxy tryptamine (5HT) and mucunian in the hair (Armstrong et al., 1953, Saltry, 1990). Some reports show that anti-histaminics afford protection against the itch (Broadbent, 1953). The antimicrobial activity (against gram positive, gram 
negative and spore forming bacteria and also fungi) of the methanol extract of the leaf of M. pruriens has been reported. Some of the medicinal properties attributed to the plant include that the roots are thermogenic, antihelminthic, and also used to relieve constipation, neuropathy and ulcers (Warrier et al., 1996). The leaves of M. pruriens are also used in the management of ulcers, cephalgia and general debility. The seeds have been known to contain large amounts of proteins and minerals and with high calorific value, but also with high levels of antinutritive properties such as phenolics, tannins, L-dopa, trypsin inhibitors, and phyto haemagglutinins (Vadivel and Janardhanan, 2000). The seed also contains glutathione, lecithin, gallic acid, nicotine, prurenidine (Rastogi and Kavathekar, 1991), and 4-tetra isoquinoline alkaloids (Misra and Wagner, 2004), The seed powder also has hypoglycaemic (Agharkar, 1991; Akhtar et al., 1990), anti snake venom activity by activation of prothrombin (Guerranti et al., 2002) and anti oxidant properties (Tripathi and Upadhyay, 2002).

Despite the appreciable progress made in the management of various diseases using conventional drugs, the search for plant-derived drugs still continues (Adeneye et al., 2007). This is also in accordance with the World Health Organization (WHO) recommendation on the evaluation of plants' effectiveness in conditions where modern drugs are lacking and as a result of various side effects of conventional drugs, this study made attempt to evaluate antiplasmodial potential of Mucuna pruriens leaves and by extension, its nutrients and phytochemical contents.

\section{Materials and methods:}

Sample collection and authentication

The fresh leaves of Mucuna pruriens were collected from Kogi State, Nigeria. It was authenticated at the Haberium Unit of Department of Botany, Kogi State University, Nigeria.

\section{Sample preparation and extraction}

The leaves of Mucuna pruriens were dried under room temperature for $72 \mathrm{hrs}$ and pulverized into powdered form using warring commercial blender. The powdered sample $(500 \mathrm{~g})$ was defatted with $400 \mathrm{ml}$ hexane $\left(\mathrm{C}_{6} \mathrm{H}_{14}\right)$ using Soxhlet extractor for $5 \mathrm{~h}$. The defatted powder samplel was air-dried and then extracted with $400 \mathrm{ml}$ ethanol $\left(\mathrm{C}_{2} \mathrm{H}_{5} \mathrm{OH}\right)$ for $8 \mathrm{~h}$. The residue was dried over night and then extracted with $250 \mathrm{ml}$ water $\left(\mathrm{H}_{2} \mathrm{O}\right)$ using a shaking water bath at $70^{\circ} \mathrm{C}$ for $2 \mathrm{~h}$. The extraction with water was repeated three times. The water filtrates were mixed together. The ethanol and water extracts were filtered and evaporated in a rotary evaporator and freeze dryer to give the crude-dried extract. The dried extracts were stored at $-20^{\circ} \mathrm{C}$ until used.

Calculation: Percentage yield $(\%)=$ weight of the plant extract $\quad \times 100$

Weight of the dried plant sample used

Proximate analysis of Mucuna pruriens leaves

Moisture content, ash, crude fat and carbohydrate were determined using AOAC, (1990) method.

\section{- Determination of Moisture Content:}

Exactly $10 \mathrm{~g}$ of the extract was dried at $103^{\circ} \mathrm{C}$ to a known weight in an oven.

Percentage Moisture Content $=\underline{\text { Weight loss after drying for } 2 \mathrm{hrs}} \times 100$

$$
\text { Weight of sample used }
$$

\section{- Determination of Ash content:}

Exactly $5 \mathrm{~g}$ of the crude extract were put into a weighed crucible and incinerated in an oven at $300^{\circ} \mathrm{C}$ for 3 days. The weight after incineration was taken. The ash content was determined as follows;

Percentage Ash Content $=$ Weight loss after incineration $\quad \times 100$

Initial weight of crucible and extract

\section{- Determination of Crude fat:}

Crude fat was determined by defating the known weight of the seed sample of $5 \mathrm{~g}$ in $25 \mathrm{ml}$ petroleum ether for $30 \mathrm{mins}$. The supernatant was decanted into weighed crucibles and oven dried for $45 \mathrm{mins}$ at $103^{\circ} \mathrm{C}$.

Percentage Crude fat $=\underline{\text { Loss of weight of supernatant }} \times 100$

Weight of sample used

\section{- Determination of Carbohydrate content:}

This was determined using Benedict's reagent method; 5 drops of the crude extract was added to $2 \mathrm{ml}$ of Benedict's reagent and placed in a boiling water bath for 5mins. A corresponding rust- brown colour was observed indicating the presence of carbohydrate.

Percentage Carbohydrate $=$ Loss of weight after incineration $\times 100$

Initial weight of crucible and extract 


\section{Phytochemical screening}

The ethanol extract of Mucuna pruriens leaves were screened for the presence of phytochemical compounds using preliminary phytochemical analysis as described by Trease and Evans (1983).

Alkaloids: To $1.0 \mathrm{ml}$ of the ethanol extract, few drops of dragendorf reagent were added. An orange colour developed indicating the presence of alkaloid.

Flavonoids: $1.0 \mathrm{ml}$ of the ethanol extract was heated with $10 \mathrm{ml}$ of ethyl acetate over a stem bath for $3 \mathrm{~min}$. The mixture was filtered and $4 \mathrm{ml}$ of the filtrate was shaken with $1 \mathrm{ml}$ of dilute ammonia solution. A yellow colouration was observed indicating a positive test for flavonoids.

Tannins (Ferric Chloride test): $1.0 \mathrm{ml}$ of the ethanol extract was diluted with $4.0 \mathrm{ml}$ of distilled water (in a ratio $1: 4$ ) and few drops of $10 \%$ ferric chloride solution were added. Blue or green precipitate or colouration formed indicates the presence of tannins.

Saponins: To $0.5 \mathrm{ml}$ of the ethanol extract, $5.0 \mathrm{ml}$ of distilled water was added and shaken vigorously for $2 \mathrm{mins}$. Then few drops of olive oil were added. Formation of emulsion indicated the presence of saponins.

Steroids: To $2 \mathrm{ml}$ of acetic anhydride was added to $0.5 \mathrm{ml}$ of the ethanol extract with $2 \mathrm{ml} \mathrm{H}_{2} \mathrm{SO}_{4}$. The colour changed from violet to blue indicating the present of steroids.

Terpenoids (Salkowaski test): $0.5 \mathrm{ml}$ of the ethanol extract was mixed in $2 \mathrm{ml}$ of chloroform, and concentrated $\mathrm{H}_{2} \mathrm{SO}_{4}(3 \mathrm{ml})$ was carefully added to form a layer. A reddish brown colouration of the inter face was formed to show positive results for the presence of Terpenoids.

Anthraquinones: $0.5 \mathrm{~g}$ of the ethanol extract was boiled with $10 \mathrm{ml} \mathrm{H}_{2} \mathrm{SO}_{4}$ and filtered while hot. The filtrate was shaken with $5 \mathrm{ml}$ of chloroform. The chloroform layer was pipette into another test tube and $1 \mathrm{ml}$ of dilute ammonia was added. The resulting solution was observed for colour changing from red to yellow.

Cardiac Glycosides (keller-Killani test): $0.5 \mathrm{ml}$ of ethanol was treated with $2 \mathrm{ml}$ of glacial acetic acid containing one drop of ferric chloride solution. This was underlayed with $1 \mathrm{ml}$ of concentrated sulphuric acid. A brown ring at the interface indicates a deoxy sugar characteristic of cardenlides. A violet ring may appear below the brown ring, while in the acetic acid layer, a greenish ring may form just gradually throughout thin layer.

Animal management

Experimental mice with weight ranging from 20 - 33g were purchased from the animal house at Markurdi. The animals were housed in steel cages and kept at room temperature. The animals had no history of drug consumption that is; they had not been used for any investigation. They were fed on pelleted commercial growers mash (VitalFeeds, Jos, Nigeria), clean tap water and were pre-conditioned for 21 days before the start of the experiment.

\section{Induction of malaria parasite and experimental grouping}

Exactly $0.2 \mathrm{ml}$ of parasitized human blood of blood group $\mathrm{O}^{+}$obtained from Bepos clinic in Masaka, was injected into the mouse of about $30.20 \mathrm{~g}$ in weight and was observed for 3 days ( 72 hours) for general symptoms of malaria. The tail was punctured from which a representative quantity of blood was obtained and a thick blood film for malaria parasite was prepared. On examination under the light microscope (x10 resolution), several malaria parasites were found, showing the mouse was positive for malaria parasite. The parasitized mouse was sacrificed and from it, blood was obtained and diluted using normal saline in the proportion of 9:1 ( $9 \mathrm{ml}$ of blood: $1 \mathrm{ml}$ of normal saline), with which the rest of the mice were induced with malaria parasite.

A total number of 30 albino mice were used for the research study. The mice were randomly grouped into six groups (A, B, C, D, E, and F) with 5 mice in each group. Group A served as the normal control (no induction), and the rats in the group were given normal saline $(1 \mathrm{ml} / \mathrm{kg} /$ body weight). Group B served as the experimental control (the parasite was induced but no treatment administered), Group C, D, and E were all induced with the parasite and treated with ethanol extracts of the leaves of Mucuna pruriens $(40 \mathrm{mg} / \mathrm{kg}, 80 \mathrm{mg} / \mathrm{kg}$, and $120 \mathrm{mg} / \mathrm{kg}$ of extracts respectively). Group F served as the standard control (the mice were induced and treated with $0.1 \mathrm{ml}$ of artesunate).

\section{Determination of parasitemia level in experimental mice}

Blood sample from experimental mice were collected from the tail vein. The level of parasitemia was then determined by the preparation of a stained thick as well as thin blood smear (thick smear is for identification of malaria parasite and thin smear for identification of species) which was viewed by the use of a microscope. The level of parasitemia was determined once daily and was closely monitored beginning from 24 hours after induction for 3 days. 


\section{Results}

Proximate composition of Mucuna pruriens leaves shows appreciable percentage of various nutrients with carbohydrate having the highest value of $(45.65 \%)$ and the crude fat content having the lowerest percentage $(2.97 \%)$ (Table 1).

Table 1: Proximate composition of Mucuna pruriens leaves

\begin{tabular}{|l|l|}
\hline PARAMETER & COMPOSITION (\%) \\
\hline Carbohydrate & 45.65 \\
\hline moisture & 11.37 \\
\hline Crude fat & 2.97 \\
\hline Ash content & 3.00 \\
\hline
\end{tabular}

The results of the phytochemical analysis of Mucuna pruriens leave extracts show the presence of phytochemical compounds as listed in Table 2 .

Table 2: Phytochemical analysis of dried leave extracts of Mucuna pruriens

\begin{tabular}{|l|l|}
\hline Phytoconstituent(s) & Mucuna pruriens leaves \\
\hline Alkaloids & ++ \\
\hline Saponins & ++ \\
\hline Flavonoids & ++ \\
\hline Cardiac glycosides & ++ \\
\hline Tannins & + \\
\hline Anthraquinones & + \\
\hline Terpenoids & + \\
\hline Steroids & + \\
\hline
\end{tabular}

The level of parasitemia increased rapidly from 24 hours after intraperitoneal administration of the parasitized blood in the experimental animals. The level of parasitemia was highest on the first day of treatment and lowest on the last day. The group treated with $120 \mathrm{mg} / \mathrm{kg}$ body weight of extract of M. pruriens produced significant reduction in the level of parasitamia, compared to the $40 \mathrm{mg} / \mathrm{kg}$ and $80 \mathrm{mg} / \mathrm{kg}$ of the extract, while the standard control group treated with artesunate showed the most significant reduction in the level of parasitamia. The experimental control group shows the highest level of parasitemia which was on the increase from the first day to the last day (Table 3 and figure 1).

Table 2: Effects of varying concentrations of ethanol extract of $M$. pruriens leaves on the level of parasitemia in experimental mice (parasite per field)

\begin{tabular}{|l|l|c|c|c|}
\hline EXPERIMENTAL GROUPS & DOSAGES & DAY 1 & DAY 2 & DAY 3 \\
\hline Normal Control & None & Nil & Nil & Nil \\
\hline Experimental Control & None & $27 \pm 2.12^{\mathrm{e}}$ & $31 \pm 2.74^{\mathrm{d}}$ & $34 \pm 2.45^{\mathrm{d}}$ \\
\hline Experimental Group 1 & $40 \mathrm{mg} / \mathrm{kg}$ extract & $21 \pm 1.58^{\mathrm{d}}$ & $19 \pm 1.87^{\mathrm{c}}$ & $15 \pm 1.87^{\mathrm{c}}$ \\
\hline Experimental Group 2 & $80 \mathrm{mg} / \mathrm{kg}$ extract & $15 \pm 1.87^{\mathrm{c}}$ & $13 \pm 2.55^{\mathrm{b}}$ & $10 \pm 2.55^{\mathrm{b}}$ \\
\hline Experimental Group 3 & $120 \mathrm{mg} / \mathrm{kg}$ extract & $12 \pm 2.55^{\mathrm{b}}$ & $10 \pm 3.08^{\mathrm{b}}$ & $8 \pm 2.74^{\mathrm{b}}$ \\
\hline Standard Control & & & & \\
\hline
\end{tabular}

Values are mean for determinations \pm SD. Values with different superscripts vertically differ statistically $(\mathrm{P}<$ $0.05)$. 


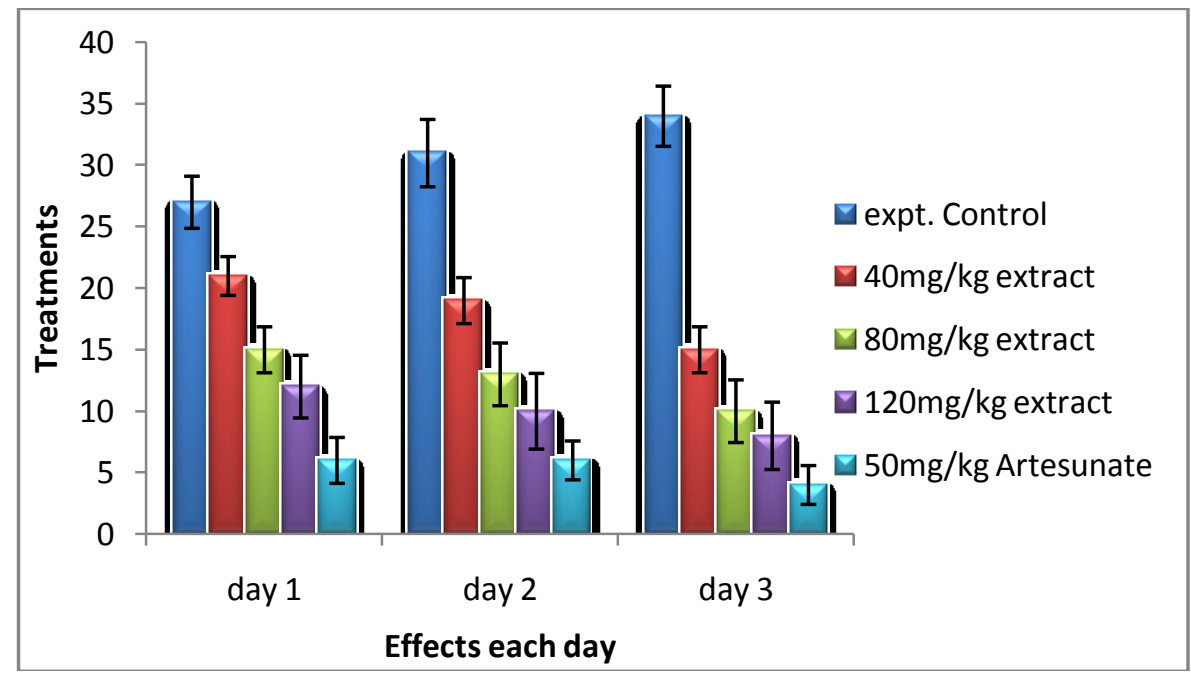

Figure 1: Effects of varying concentrations of ethanol extract of M. pruriens leaves on the level of parasitemia in experimental mice following 3 days intraperitonial administration

\section{Level of parasitemia and feed intake in experimental animals for the period of treatment}

The least amount of food was consumed on the first day. Tiredness and sluggishness was observed in the experimental animals, during this period. On the second day, an average level of parasitemia and feed intake was recorded. The last day of treatment recorded the highest amount of feed consumed and the least level of parasitemia, except for the experimental control (Group B) in which low amount of feed was consumed and high level of parasitamia was recorded (Table 3, 4 and figure 2).

Table 4: mean amount of feed intake (g)

\begin{tabular}{|l|l|c|c|c|}
\hline Experimental groups & Dosages & Day 1 & Day 2 & Day 3 \\
\hline Normal Control & None & 50 & 50 & 50 \\
\hline Experimental Control & None & 4.5 & 3.5 & 3.0 \\
\hline Experimental Group 1 & $40 \mathrm{mg} / \mathrm{kg}$ extract & 4.0 & 5.7 & 28.0 \\
\hline Experimental Group 2 & $80 \mathrm{mg} / \mathrm{kg}$ extract & 4.5 & 10 & 30.5 \\
\hline Experimental Group 3 & $120 \mathrm{mg} / \mathrm{kg}$ extract & 3.0 & 12 & 35.5 \\
\hline Standard Control & $50 \mathrm{mg} / \mathrm{kg}$ Artesunate & 3.5 & 14 & 41 \\
\hline
\end{tabular}

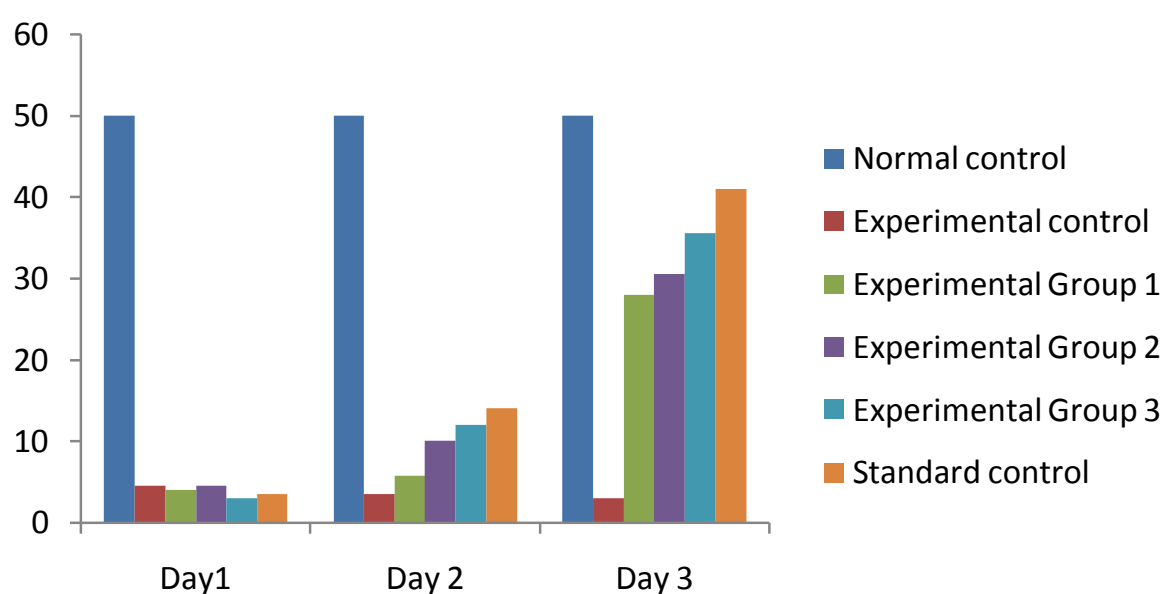

Figure 2: mean feed intake in the experimental mice 


\section{Discussion}

Proximate composition of Mucuna pruriens leaves showed appreciable percentage of various nutrients with carbohydrate having the highest value of $(45.65 \%)$ and the crude fat content having the lowest percentage (2.97\%). This shows that Mucuna pruriens leaves can serve as a good source of nutrient. Phytochemical analysis of the leaves showed presence of phytochemical compounds indicating that the leaves have medicinal properties which is in line with the fact that the curative properties of plant derived drugs are due to the presence of complex chemical substances of varied composition in one or more parts of the plants. Polyphenols are abundant in our diet, and play important role in the prevention of various diseases associated with oxidative stress (Claudine et al., 2004).

The antiplasmodial potential observed with the ethanol extracts of this plant might be attributed to the presence of these phytochemical compounds in the plant (Peter and Anatoli, 1998). This result indicates that the ethanol extract of M. pruriens leaf reduced the parasitaemia in suppressive models in a dose dependent fashion. Plants are known to exert antiplasmodial activity either by direct or indirect action on the parasite depending on their phytochemical constituents (Misra et al., 1991). Previous study on Mucuna pruriens plant has implicated alkaloids to be the bioactive compound responsible for its various activities (Reddy et al., 2008). This correlate with the result obtained from qualitative phytochemical analysis where Alkaloids have also been implicated in antiplasmodial activities of many plants. For example, the alkaloid constituents of Hydrangea macrophylla var. Otaka was found to affect the host immune mechanism contributing to acquired immunity to blood-stage malaria instead of a direct action on parasites (Ishih et al., 2001). This effect was further attributed to macrophage activation which includes production of oxygen radicals that ultimately lead to the clearance of infected red blood cells (Hisaeda et al., 2005).

The ethanol extract of M. pruriens for the experimental groups treated with $40 \mathrm{mg} / \mathrm{kg}$ and $80 \mathrm{mg} / \mathrm{kg}$ recorded troughs of parasitemia, while the group treated with $50 \mathrm{mg} / \mathrm{kg}$ artesunate and $120 \mathrm{mg} / \mathrm{kg}$ of the extract recorded just a few on the third day, which means that the dosages were not potent enough to clear the parasitaemia completely after three days of treatment. The result in Table 3 and figure 1 showed that the first day of treatment recorded the highest number of parasitaemia per field and this gave a significant reduction of parasitaemia, when compared to the experimental control group.

The last day of treatment recorded the highest amount of feed consumed and the least level of parasitemia, except for the experimental control (Group B) in which low amount of feed was consumed and high level of parasitamia was recorded. The suppressive potential of the ethanol extract of M. pruriens showed a dose dependent schizonticidal effect on the parasitaemia similar to artesunate treated group. The results of this study demonstrated that M. pruriens possess considerable intrinsic antiplasmodial activity, which can be attributed to its phytochemical compounds.

\section{Conclusion}

From this study, it can be concluded that the ethanol extract of Mucuna pruriens leaves possess significant suppressive effects on P. falciparum malaria. Therefore, it may be a therapy for the treatment of malaria, either alone or in combination with another drug.

\section{References}

[1] Adeneye, A. A., Adeleke, T. I., and Adeneye, A. K. (2007).Journal of Ethnopharmacology,116: 7-10.

[2] Agharkar S. P. (1991). Medicinal Plants of Bombay Presidency. Sci. Pub. Jodhpur pp 1- 2.

[3] Akhtar M. .S., Quereshi A. O. and Iqbal J. I. (1990). Antidiabetic evaluation of Mucuna pruriens Linn. Seeds. J. Pak Med Assoc. 40 (7): $147-150$.

[4] Amin K. M. Y., Khan M. N. and Zithur-Rehman S. (1996). Sexual function improving effect of Mucuna pruriens in sexually normal male rats. J. Study med. Plant. Fitoterapia. 61(1) 53-58.

[5] Armstrong D., Arcy R. M. L., Keela C. A., Maikhana M., (1953). Observations on chemical excitants of cutaneous pain in man. J. Physiol. 120: 326-351.

[6] Atawodi, S.E., Atawodi, J.C., Pala Y Idakwo P. (2009) Assessment of the Polyphenol Profile and Antioxidant Properties of Leaves, Stem and Root Barks of Khaya senegalensis (Desv.). Electronic Journal of Biology,5(4):80 - 84

[7] Bako S. P., Bakfur M. J., John I., Bala E. I., (2005). Ethnomedicinal and Phytochemical profile of some savanna plant species in Nigeria. Int. J. Bot., 1 (2): 147-150

[8] Bhasin S., Storer T. W., Berman N., Callegari C., Clevenger B., Phillips J., Bunnell T. J., Ricker R., Shirazi A., Casaburi R., (1996). The Effects of Supraphysiologic Doses of Testosterone on Muscle Size and Strength in Normal Men. N. Engl. J. Med., 335 : 1-7.

[9] Broadbent J. L. (1953). Observation on itching produced by Cowhage and on the part played by histamine as a mediator of the itch sensation. Brit. J. Pharmacol. Chemother. 8: 263-270.

[10] Elujoba A. A. (1997). The role of pharmacognosy in phytotherapy the challenges of our time. Nig. J. of Nat. Prod., 2: 34-36.

[11] Claudine, M.Augustin, S. Christine, M. Christian, R. and Liliana, J. (2004). Polyphenols: food sources and bioavailability. Am J ClinNutr,79:727-47.

[12] Guerranti R., Aguiyi J. C., Neri S., Leoncini R., Pagoni R., Marinello E. (2002). Proteins from Mucuna pruriens and enzymes from Echis carinatus Verom. The J. Biol. Chem. 277(19): 17072-17078.

[13] Hisaeda H., Yasutomo K. \& Himeno K. (2005) Malaria: immune evasion by parasites. The International Journal of Biochemistry and Cell Biology 37: 700-706. 
[14] Ishih A., Ikeya C., Yanoh M., Takezoe H., Miyase T. \& Terada M. (2001) A potent antimalarial activity of Hydrangea macrophylla var. Otaksa leaf extract against plasmodium yoelii $17 x \mathrm{x}$ in mice. Parasitology International 50:33-39.

[15] Manyam B. V., Dhanasekaran M. and Hare T. (2004) Phytotherapy Research., 18, 706-712.

[16] Mendonca-Filho, R. R. (2006). Bioactive phytocompounds: New Approaches in the phytosciences. Modern Phytomedicine 1-24.

[17] Misra L. and Wagner H. (1991). Alkaloid constituents of Mucuna pruriens seeds. Phytochemistry. 65(18): 2565 - 2568.

[18] Obadoni B. O. and Ochuko P. O. (2001) Phytochemical studies and comparative efficacy of the crude extracts of some haemostatic plants in Edo and Delta States of Nigeria. Global J.Pure Appl. Sci. 8: 203 - 208.

[19] Peter L. T and Anatoli V. K. (1998). The Current Global Malaria situation. Malaria parasite Biology, pathogenesis and protection. ASM Press. Washington, DC, pp: 11-22.

[20] Reddy V. B., Luga A. O., Shimada S. G., LaMotte R. H. \& Lerner E. A. (2008) Cowhage evoked itch is mediated by a novel cysteiine protease- a ligand of protease activated receptors. Journal of Neuroscience 28 (17):4331-4335.

[21] Sastry C. S. J. and Methrotas B. N. (1991). Plants for reclamation of waste lands. Publication and information Directorate. New Delhi. pp $317-318$

[22] Sofowora E.A (1982). The State of Medicinal Plants' Research in Nigeria. Ibadan University Press, Nigeria, p. 404

[23] Taylor L. (2005). The Healing Power of Rainforest Herbs. J. Nat. Prod., 56: pp 44.

[24] Trease G. E. \& Evans W. C. (1983). Pharmacognosy. 11th Edition Brailliar Trindel Can. MacMillian Publishers. Pp 80

[25] Tripathi Y. B. and Upadhyay A. K. (2002). Effect of the ethanolic extracts of the seeds of Mucuna prurienson free radicals and oxidative stress in albino rats. Phytotherap Res. 16(6): $534-538$.

[26] Vadivel V. and Janardhanan K. (2000). Nutritional and anti - nutritional composition of velvet beans: an underutilized food legume in South India. Int J. Food Sci Nutri. 51(4): 279-87.

[27] Warrier P. K., Nambiar V. K. P. and Ramankutty C. (1996). Indian Medicinal Plants (vol 4). Orient Longman, Chemai, India. pp 68 -72 . 